\title{
Chronic exposure to a neonicotinoid pesticide and a synthetic pyrethroid in full-sized honey bee colonies
}

\author{
Richard ODEMER ${ }^{1}$, Peter ROSENKRANZ ${ }^{1}$
}

\author{
${ }^{1}$ University of Hohenheim, Apicultural State Institute, 70593 Stuttgart, Germany
}

*Corresponding Author: richard.odemer@uni-hohenheim.de phone: +4915751302602

Keywords: neonicotinoid; thiacloprid; pyrethroid; $\tau$-fluvalinate; honey bees; population dynamics; overwintering success; colony level

\section{ACKNOWLEDGEMENTS}

We appreciate the support of the LAB staff for helping with the artificial swarms and colony assessments. This work was supported by the $7^{\text {th }}$ Framework EU Programme Grant "BEE DOC" under Grant number 244956 CP-FP.

\footnotetext{
ABSTRACT

In the last decade, the use of neonicotinoid insecticides increased significantly in the agricultural landscape and meanwhile considered a risk to honey bees. Besides the exposure to pesticides, colonies are treated frequently with various acaricides that beekeepers are forced to use against the parasitic mite Varroa destructor. Here we have analyzed the impact of a chronic exposure to sublethal concentrations of the common neonicotinoid thiacloprid (T) and the widely used acaricide $\tau$-fluvalinate (synthetic pyrethroid, F) - applied alone or in combination - to honey bee colonies under field conditions. The population dynamics of bees and brood were assessed in all colonies according to the Liebefeld method. Four groups (T, F, $\mathrm{F}+\mathrm{T}$, control) with 8-9 colonies each were analyzed in two independent replications, each lasting from spring/summer until spring of the consecutive year. In late autumn, all colonies were treated with oxalic acid against Varroosis. We could not find a negative impact of the chronic neonicotinoid exposure on the population dynamics or overwintering success of the colonies, irrespective of whether applied alone or in combination with $\tau$-fluvalinate. This is in contrast to some results obtained from individually treated bees under laboratory conditions and confirms again an effective buffering capacity of the honey bee colony as a
} 
superorganism. Yet, the underlying mechanisms for this social resilience remain to be fully understood.

\section{INTRODUCTION}

Neonicotinoid pesticides are among the most used insecticides during the past decades and are dominating the global market for insecticidal seed dressings (Jeschke et al., 2011; SimonDelso et al., 2015). However, these neonicotinoids are suspected to be a main driver for the decline of honey bees (Hopwood et al., 2016), wild bees (Potts et al., 2010) and even nontarget wildlife in general (Goulson, 2013). Recently, the European Food Safety Authority (EFSA) has updated their risk assessment and now considers the three neonicotinoids imidacloprid, clothianidin and thiametoxam to be "a risk for bees" and suggested suitable amendments to the European Commission (EFSA, 2018). These three nitro-substituted compounds have the highest toxicity to bees among the class of neonicotinoids (Iwasa et al., 2004) and have been already banned for the use in flowering crops by the European Union since the year 2014 (EFSA, 2013).

However, other neonicotinoid insecticides with a far lower toxicity to bees - for instance thiacloprid and acetamiprid - are still widely used not only as seed dressings but are even approved as foliar spray in blooming cultures like oilseed rape (Schmuck et al., 2003). This leads to a remarkable high contamination of nectar and pollen and foragers might therefore be continuously exposed to these agents (Genersch et al., 2010; Collison et al., 2016; Rolke et al., 2016; Böhme et al., 2017). There is no doubt about the comparable low acute toxicity of these compounds to bees, however there is a controversial discussion on sublethal and longterm effects. So, it has been shown that thiacloprid can affect the sensitivity of honey bees to the gut parasite Nosema ceranae (Vidau et al., 2011; Pettis et al., 2013; Retschnig et al., 2015). More recent publications indicate that sublethal concentrations of thiacloprid alter their social behavior (Forfert and Moritz 2017) and, more importantly, disturb the orientation of foragers (Fischer et al., 2014; Tison et al., 2016, 2017). These studies have been conducted on the level of individual or small groups of bees by performing cage tests or semi-field trials under rather artificial conditions. Therefore, they do not cover important attributes of a social entity, with a more complex perception to its environment. Hence, the transfer of these results to field conditions must be taken with caution. Significantly, the only field study available so far could not confirm negative effects of thiacloprid at the colony level (Siede et al., 2017). 
Another controversial point is the possible interaction of thiacloprid - considered as "nontoxic for bees" - with active compounds of other chemical classes that are applied by beekeepers to control the parasitic mite Varroa destructor, requiring multiple annual treatments (Rosenkranz et al., 2010). In an effective and easy to use application, synthetic pyrethroids were, amongst others, introduced to beekeepers (Watkins, 1997) and are besides the formamidine amitraz the most frequently used acaricides in apiculture (Garrido et al., 2016). The exposure of honey bee colonies to a combination of sublethal doses of such pesticides may increase the susceptibility to pathogens and are suspected to contribute to the worldwide health problems of honey bee colonies (Cornman et al., 2013; Matsumoto, 2013; $\mathrm{Wu}$ et al., 2012). To study such possible combination effects we have chronically exposed full-sized colonies to the neonicotinoid thiacloprid and the synthetic pyrethroid $\tau$-fluvalinate $\left(\right.$ Apistan $^{\circledR}$ ) in a two-year field study. To our knowledge this is the first study that analyzes the effect of a chronic application of both, a neonicotinoid insecticide and a common acaricide under realistic field conditions at the colony level. An exposure to these two pesticides is very likely under common beekeeping conditions in rural areas. Our crucial endpoints were (i) the overwintering success of treated colonies compared to untreated controls and (ii) the colony population dynamics.

\section{MATERIALS \& METHODS}

\subsection{Experimental colonies}

For each treatment group, five experimental colonies were established in early May of the year 2010. The experiment was repeated with three to four new colonies per group in the year 2011 (Tab. 1). All colonies were set up at our local apiary at the agricultural experimental station Kleinhohenheim, which is an organic farming facility not using any agro chemicals or common pesticides at all. To standardize our experiment, we used artificial swarms made from stock colonies that were screened for low Varroa infestation and lack of virus infections prior to the trials. Freshly reared and mated sister queens of the Hohenheim breeding line were provided to each swarm, respectively. After the colonies successfully showed the first open brood stages, we sprayed all of them with a $3.5 \%$ oxalic acid sugar solution for Varroa treatment to have a comparable low mite infestation for all experimental groups at the start of the experiment. We used residue free beeswax foundations to minimize the risk of additional contamination through pesticide residues in the wax (Bogdanov et al., 1998; Wallner, 1999). 
All colonies were set up on one box of 10 Zander frames, which was extended to two boxes when necessary during the summer season.

Tab. 1: List of replications, treatment groups, treatment duration, assessment dates (AD) and no. of colonies (N) at the time of the assessment.

\begin{tabular}{|c|c|c|c|c|c|c|c|c|c|c|c|c|}
\hline Year & Treatment & $\begin{array}{c}\text { Duration } \\
\text { [days] }\end{array}$ & AD 1) & $\mathbf{N}$ & AD 2) & $\mathbf{N}$ & AD 3) & $\mathbf{N}$ & $\begin{array}{c}\text { Winter } \\
\text { treatment }\end{array}$ & $\mathbf{N}$ & AD 4) & $\mathbf{N}$ \\
\hline \multirow{4}{*}{$\begin{array}{l}2010- \\
2011\end{array}$} & Control & \multirow{4}{*}{56} & \multirow{4}{*}{ 23. Jul } & 5 & \multirow{4}{*}{ 16. Aug } & 5 & \multirow{4}{*}{ 8. Oct } & 5 & \multirow{4}{*}{ 30. Nov } & 4 & \multirow{4}{*}{ 15. Apr } & 4 \\
\hline & Thiacloprid & & & 5 & & 5 & & 5 & & 3 & & 3 \\
\hline & Fluvalinate & & & 5 & & 5 & & 5 & & 5 & & 5 \\
\hline & Flu + Thia & & & 5 & & 5 & & 5 & & 4 & & 4 \\
\hline \multirow{4}{*}{$\begin{array}{l}2011- \\
2012\end{array}$} & Control & \multirow{4}{*}{62} & \multirow{4}{*}{ 21. Apr } & 3 & \multirow{4}{*}{ 5. Aug } & 3 & \multirow{4}{*}{ 13. Oct } & 3 & \multirow{4}{*}{ 29. Dec } & 3 & \multirow{4}{*}{ 3. Apr } & 2 \\
\hline & Thiacloprid & & & 4 & & 4 & & 4 & & 4 & & 4 \\
\hline & Fluvalinate & & & 3 & & 3 & & 3 & & 3 & & 3 \\
\hline & Flu + Thia & & & 3 & & 3 & & 3 & & 3 & & 3 \\
\hline
\end{tabular}

\subsection{Thiacloprid application}

For the application of thiacloprid we used the pure substance (98\% purity, Dr. Ehrenstorfer $\mathrm{GmbH}$ ), which was sonicated in pure water for a stock solution. We aimed to use a fieldrealistic concentration that was approximately 100 -fold lower than the oral $\mathrm{LD}_{50}$ for thiacloprid (173.2 mg/kg, Würfel, 2008). We therefore diluted thiacloprid in sucrose syrup (Apiinvert, Südzucker $\mathrm{GmbH}$ ) in order to receive the respective concentration. The final solution was quantified by an external lab (Eurofins Dr. Specht Laboratorien GmbH, Hamburg, Germany) which confirmed a thiacloprid concentration of $1.6 \mathrm{mg} / \mathrm{kg}(=1,600 \mathrm{ppb})$. This feeding solution was applied to the colonies of the specific treatment groups and control colonies were fed with untreated sucrose syrup. The duration of the treatment in the year 2010 was 56 days $\left(23^{\text {rd }} \mathrm{Jul}-17^{\text {th }} \mathrm{Sep}\right)$ and in the year 201162 days $\left(21^{\text {st }}\right.$ Apr-22 ${ }^{\text {nd }}$ Jun $)$ during summer season. In this time period we fed $1 \mathrm{~kg}$ syrup per week with an internal feeding device, to simulate a chronic exposure. A final amount of $8 \mathrm{~kg}$ per colony in 2010 and $9 \mathrm{~kg}$ in 2011 was administered in the summer season, respectively. Based on the concentration of $1.6 \mathrm{mg} / \mathrm{kg}$ we therefore applied a total amount of $12.8 \mathrm{mg}$ thiacloprid per colony in 8 weeks (2010) and $14.4 \mathrm{mg}$ thiacloprid per colony in 9 weeks (2011) during the summer season, respectively. The treatment was resumed when colonies were fed for overwintering at the end of the season. Every colony was fed with approximately $15 \mathrm{~kg}$ of the feeding solution with a total amount of $24.0 \mathrm{mg}$ thiacloprid in each year for winter feeding. After the treatment period 
119 in summer, a pooled sample of food (nectar/honey) from the combs was analyzed for residues

120 at Eurofins Dr. Specht Laboratorien GmbH.

\section{$2.3 \tau$-fluvalinate application}

Apistan ${ }^{\circledR}$ strips (Vita Europe Ltd, Basingstoke, UK) were used for the $\tau$-fluvalinate treatment. As recommended, one strip per box was applied to the $\tau$-fluvalinate treatment groups during the same time of the thiacloprid application. After the treatment period, a pooled sample of beeswax was analyzed for residues at our own lab in Hohenheim. During overwintering, the strips were again inserted to the colonies to resume a chronic treatment.

\subsection{Assessment of population dynamics}

The amount of bees and brood cells (open and sealed) were estimated with the Liebefelder Method (Imdorf et al., 1987), which is a feasible tool that provides accurate and reliable results at the colony level (measuring error $+/-10 \%$ ). Care was taken that all colonies were evaluated by the same person on all dates to minimize variation. Colony assessments were usually conducted in the morning before bee flight.

\subsection{Varroa winter treatment}

In order to monitor the level of mite infestation in the colonies and to measure the effectiveness of the $\tau$-fluvalinate treatment, we applied $3.5 \%$ oxalic acid sugar solution to the bees in a brood free stage during late autumn or winter time $\left(30^{\text {th }}\right.$ Nov in 2010 and $29^{\text {th }}$ Dec in 2011). In both years the temperature was below $3{ }^{\circ} \mathrm{C}$ for optimal application to a closely spaced bee cluster. Dead mites were counted approximately one week after the treatment with a sticky board, which was inserted at the same day of treatment, respectively.

\subsection{Statistical analysis}

The estimated number of bees and brood cells from both years were checked with a ShapiroWilk test for normal distribution $(\mathrm{p}>0.05)$. Therefore, a one-way ANOVA and a multiple comparison of the means with a post-hoc Bonferroni correction were performed on the four experimental groups, respectively $(\alpha=0.05)$. 


\section{$147 \quad 3 \quad$ RESULTS}

\section{$148 \quad 3.1 \quad$ Overwintering success}

149 In both years, none of the colonies died until the start of wintering in October (Tab. 1). Taken

150 both years together, a total of five of the 33 colonies died over winter. Two of the

151 "Thiacloprid" group $(\mathrm{N}=9)$, one of the "Flu+Thia" group $(\mathrm{N}=8)$, two of the "Control"

152 group $(\mathrm{N}=8)$ and none of the "Fluvalinate" group $(\mathrm{N}=8$; Tab. 1).

\section{$153 \quad 3.2 \quad$ Population dynamics}

\section{$154 \quad$ 3.2.1 Experiment $1(2010$ - 2011)}

155 The population of bees and brood cells were estimated four times during the whole season

156 (Tab. 1). The results are shown in Fig. 1a for the number of bees and in Fig. 1b for the

157 number of brood cells. We compared the four treatment groups for each date of the estimates

158 and could not see significant differences (ANOVA) for the number of bees in August 2010

159 (“AUG"; p=0.254), October 2010 (“OCT"; p=0.473) and April 2011 (“APR"; p=0.388).

160 Likewise, no significant differences of the amount of brood cells were recorded in October

1612010 (“OCT"; p=0.590) and April 2011 (“APR"; p=0.128). However, in July the number of

162 bees of the "Control" were significantly lower compared to "Fluvalinate" ( $p=0.029$,

163 ANOVA). The number of brood cells of the "Control" was significantly lower compared to

164 "Thiacloprid" and "Flu+Thia" in July ( $\mathrm{p}=0.012$, ANOVA) and compared to "Thiacloprid" in

165 August ( $\mathrm{p}=0.004$, ANOVA). 


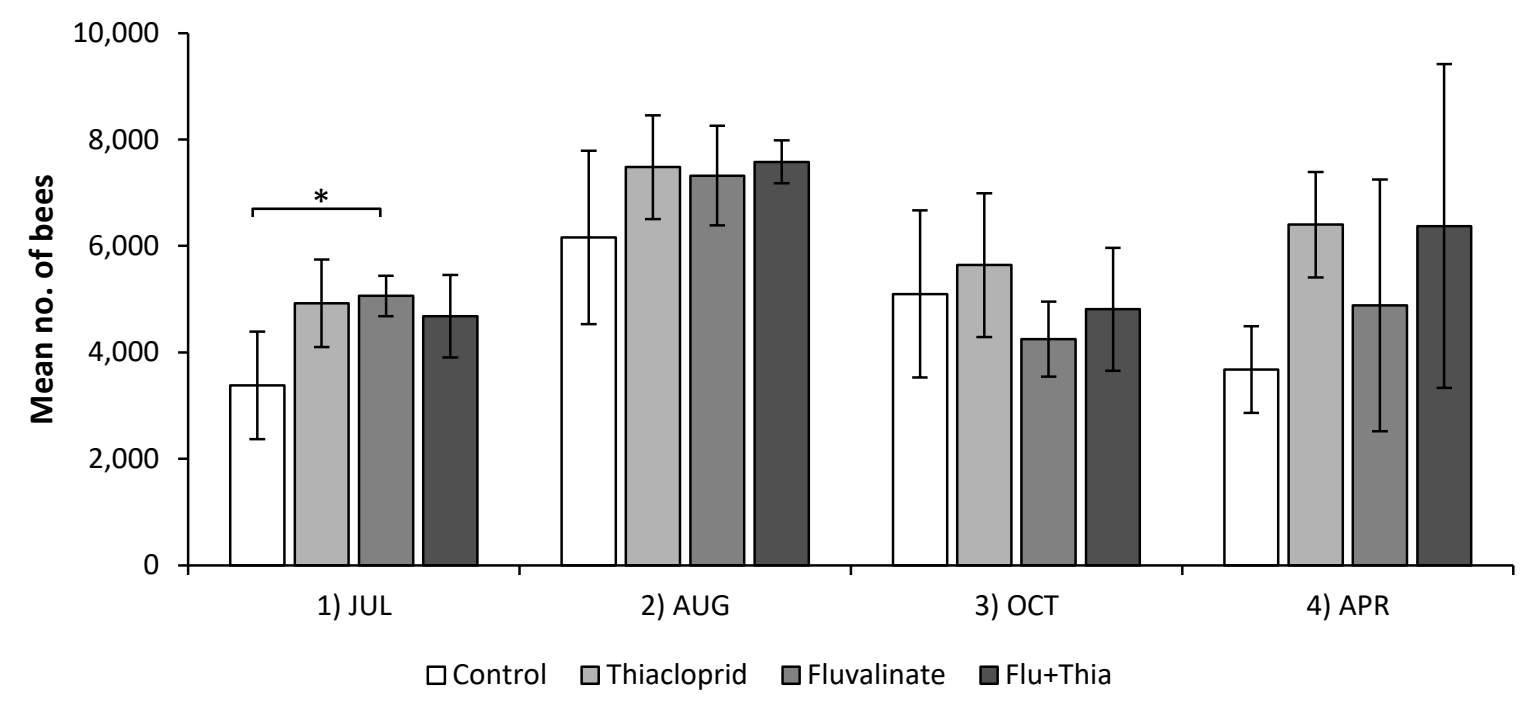

168 Fig. 1a: Number of bees estimated in the colonies in the year 2010-2011 for the four treatment groups at four

169 different assessments. * statistically significantly lower when "Control" compared to "Fluvalinate" ( $<<0.05$, ANOVA).

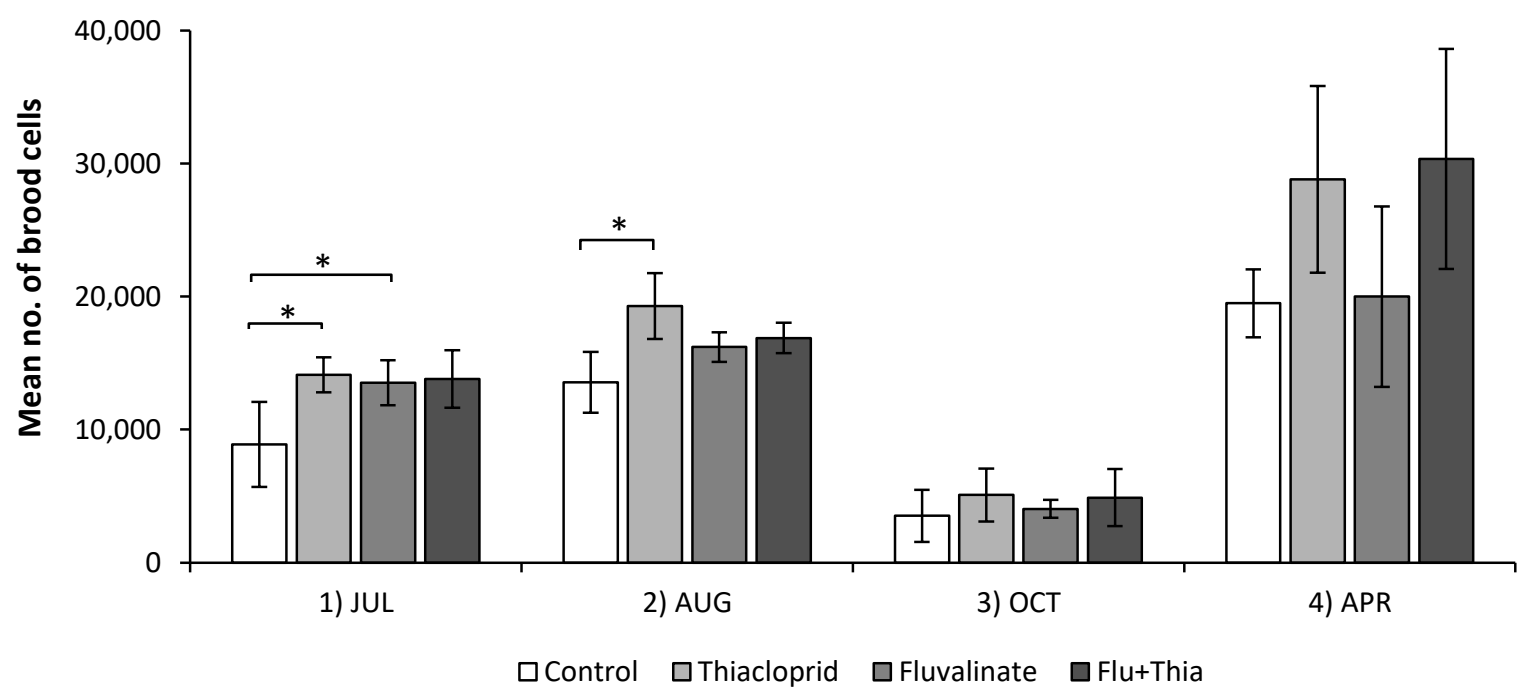

174

175 Fig. 1b: Number of brood cells estimated in the colonies in the year 2010-2011 for the four treatment groups at 176 four different assessments. * statistically significantly lower when "Control" compared to "Thiacloprid" and 177 "Fluvalinate" ( $<<0.05$, ANOVA) in 1), and when "Control" compared to "Thiacloprid" ( $<<0.05$, ANOVA) in 2). 


\subsubsection{Experiment $2(2011$ - 2012)}

180 For the replicate of experiment 1, also four assessments were performed throughout the

181 season. The results are shown in Fig. 2a for bees and in Fig. 2b for brood. We again compared

182 the four groups within each assessment but could not see any significant differences for the

183 number of bees (April $2011 \mathrm{p}=0.174$; August $2011 \mathrm{p}=0.367$; October $2011 \mathrm{p}=0.664$; April

$1842012 \mathrm{p}=0.198$ ) and no significant differences for the number of brood cells in April 2011

185 ( $\mathrm{p}=0.071)$, October $2011(\mathrm{p}=0.328)$ and April $2012(\mathrm{p}=0.176$; ANOVA). Solely, in August

186 2011, the number of brood cells in "Thiacloprid" was significantly lower compared to

187 "Control" and "Fluvalinate" ( $\mathrm{p}=0.017$, ANOVA).

188

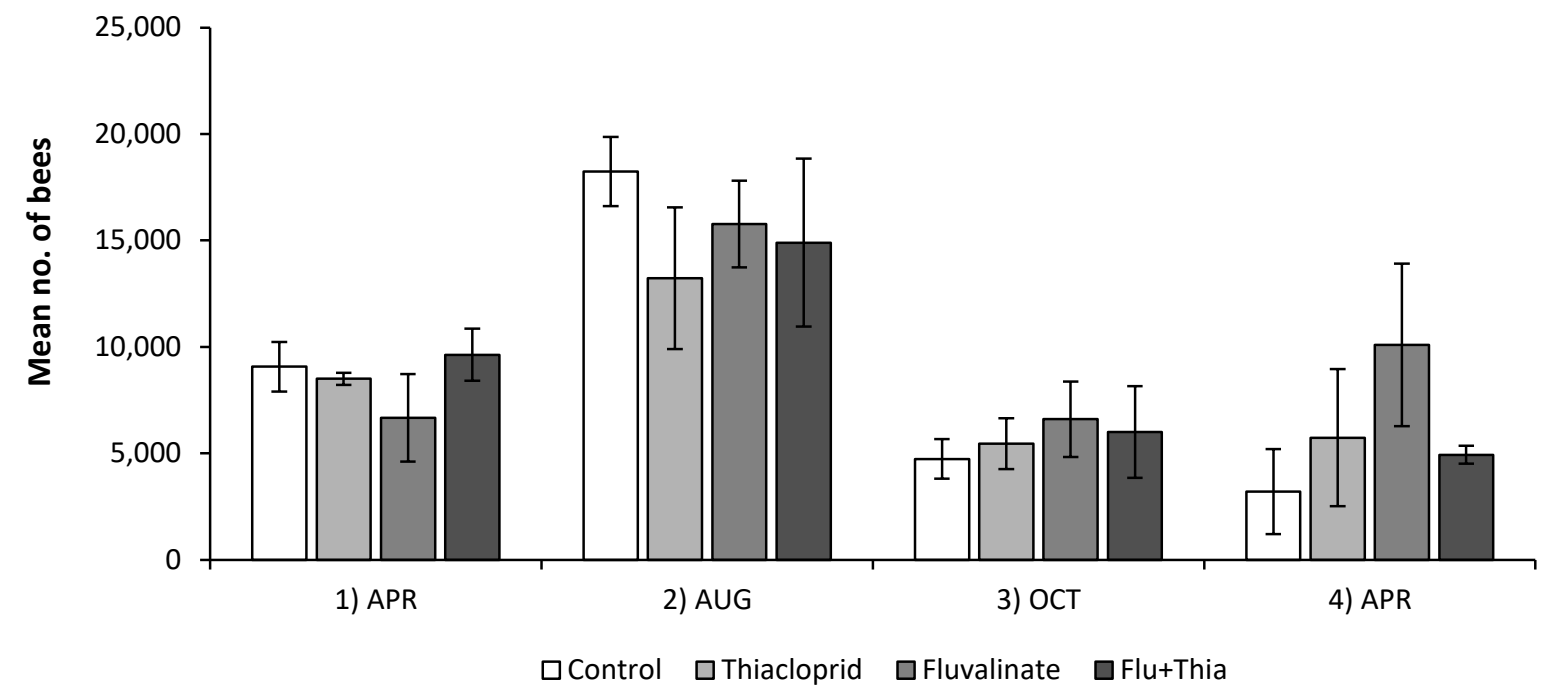

190 Fig. 2a: Number of bees estimated in the colonies in the year 2011-2012 for the four treatment groups at four 191 different assessments. We could not see statistically significant differences within the assessments ( $p>0.05$, 192 ANOVA). 


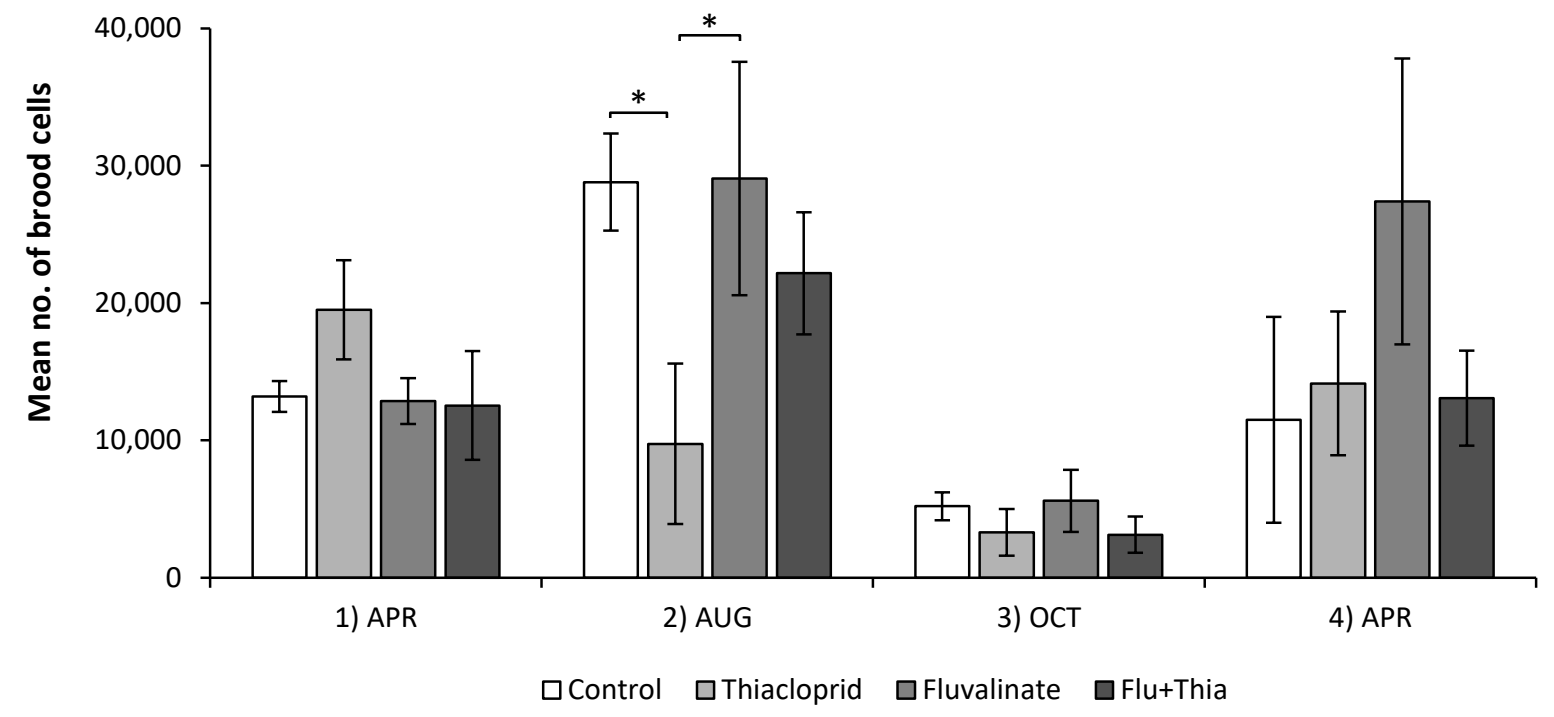

Fig. 2b: Number of brood cells estimated in the colonies in the year 2011-2012 for the four treatment groups at four different assessments. * statistically significantly lower when "Thiacloprid" compared to "Control" and "Fluvalinate" ( $\mathrm{p}<0.05$, ANOVA) in 2).

\subsection{Thiacloprid residues}

200 Food from the syrup feeding, which was processed by the bees and stored in honeycombs, was analyzed for thiacloprid residues in both years with QuEChERS method (Limit of Quantification LOQ $=0.01 \mathrm{mg} / \mathrm{kg}$ ). For the analysis, samples from all colonies and the respective groups per year were pooled. All groups without thiacloprid treatment did not have measurable residues in both years. The pooled samples from the "Thiacloprid" and "Flu+Thia" groups had residues of $0.11 \mathrm{mg} / \mathrm{kg}$ and $0.20 \mathrm{mg} / \mathrm{kg}$, respectively, in the year 2010-2011 and 0.29 mg/kg and 0.19 mg/kg, respectively, in the year 2011-2012 (Tab. 2).

\section{4 $\tau$-fluvalinate residues}

209 Beeswax was analyzed for $\tau$-fluvalinate residues in both years by solid-phase extraction (SPE) 210 and GC-ECD (LOQ $=0.5 \mathrm{mg} / \mathrm{kg}$ ). For the analysis, samples from all colonies and the 211 respective groups per year were pooled. All groups without $\tau$-fluvalinate treatment did not 212 have measurable residues in both years. Pooled samples from the "Fluvalinate" and 213 "Flu+Thia" groups had residues of $>100 \mathrm{mg} / \mathrm{kg}$ and $16.7 \mathrm{mg} / \mathrm{kg}$, respectively, in the year 214 2010-2011 and $14.3 \mathrm{mg} / \mathrm{kg}$ and $31.6 \mathrm{mg} / \mathrm{kg}$, respectively, in the year 2011-2012 (Tab. 2). 
Tab. 2: Thiacloprid residues in pooled food (syrup) samples, which was processed by the bees and stored in the honeycombs from all treatment groups in both years (QuEChERS method, LOQ $=0.01 \mathrm{mg} / \mathrm{kg}$ ). $\tau$-fluvalinate

218 residues in pooled beeswax samples from all treatment groups in both years (SPE \& GC-ECD, LOQ $=0.5$

$219 \mathrm{mg} / \mathrm{kg})$.

\begin{tabular}{cccccc} 
Year & Treatment & Matrix & $\begin{array}{c}\text { Thiacloprid } \\
{[\mathbf{m g} / \mathbf{k g}]}\end{array}$ & Matrix & $\begin{array}{c}\boldsymbol{\tau} \text {-fluvalinate } \\
{[\mathbf{m g} / \mathbf{k g}]}\end{array}$ \\
\hline \multirow{2}{*}{$2010-$} & Control & & 0 & & 0 \\
2011 & Thiacloprid & Food & 0.11 & Beeswax & 0 \\
& Fluvalinate & & 0 & & $>100$ \\
& Flu + Thia & & 0.2 & & 16.7 \\
\hline $2011-$ & Control & & 0 & Beeswax & 0 \\
2012 & Thiacloprid & \multirow{2}{*}{ Food } & 0.29 & 14.3 \\
& Fluvalinate & & 0 & & 31.6 \\
\hline & Flu + Thia & & 0.19 & - \\
\hline
\end{tabular}

\subsection{Varroa winter treatment}

223 In both years, the winter treatment with oxalic acid killed considerably fewer mites in those

224 groups that have been continuously treated with the acaricide $\tau$-fluvalinate (Fig. 3 ). In the

225 "Control" and "Thiacloprid" groups between 217 to 409 mites were killed through this winter 226 treatment, on average. In 2010, only one single mite was found in the eight $\tau$-fluvalinate 227 treated colonies! However, in both $\tau$-fluvalinate treated groups the number of mites killed by 228 the winter treatment increased in the second year to an average of 15 mites for the 229 "Fluvalinate" group and 68 mites for the "Flu+Thia" group, respectively. 


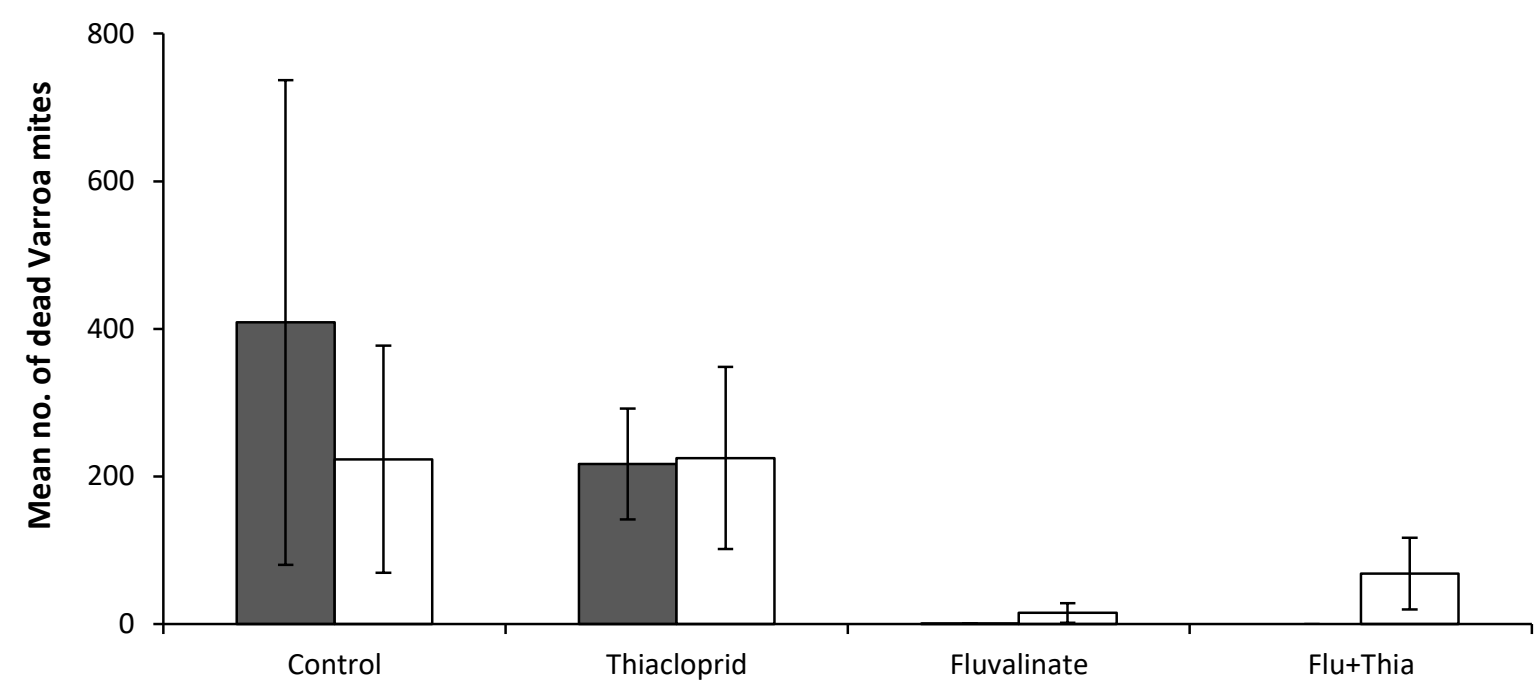

口Winter $2010 \quad \square$ Winter 2011

232 Fig. 3: Graph of the dropped Varroa mites approximately one week after oxalic acid treatment during winter 233 time (2010 and 2011). In both years a considerably lower number of dead mites could be detected in the $\tau$ 234 fluvalinate treated vs. the untreated groups. 


\section{DISCUSSION}

237 We here analyzed the effects of two commonly used pesticides on the population dynamics 238 and the overwintering success of free flying honey bee colonies. The pesticides belong to two 239 different substance classes, one a neonicotinoid insecticide and the other a synthetic 240 pyrethroid widely used as acaricide to combat varroa mites. For both, the insecticide and the acaricide, the applied dosages represent worst case scenarios. Thiacloprid is meanwhile frequently found as residue in pollen and honey, presumably due to the application in flowering oilseed rape and fruit production. Maximum peak concentrations of thiacloprid in bee products such as nectar, honey or pollen range from $\sim 0.05$ to $1 \mathrm{mg} / \mathrm{kg}$ across the globe (EFSA, 2016; Genersch et al., 2010; Laaniste et al., 2016; Mitchell et al., 2017; Mullin et al., 2012; Pohorecka et al., 2012; Smodis Skerl et al., 2009) but rarely exceed the average level of $0.2 \mathrm{mg} / \mathrm{kg}$ (reports of the German Bee Monitoring, see Rosenkranz et al., 2016). It should be mentioned that $0.2 \mathrm{mg} / \mathrm{kg}$ is also the maximum value for thiacloprid residues accepted for honey in the EU (EFSA, 2016). The continuous long-term feeding of $1.6 \mathrm{mg} / \mathrm{kg}$ thiacloprid to our experimental colonies resulted indeed in residue levels of this magnitude ranging from about 0.1 to $0.3 \mathrm{mg} / \mathrm{kg}$ in the stored food. It is interesting to note the significant 8 -folddecrease from the concentration in the original feeding syrup to the honey bee processed syrup stored in the honeycombs. This decrease might be due to a dilution effect, as all colonies could forage and had access to various nectar sources. Furthermore, Iwasa et al. (2004) and Brunet et al. (2005) reported that cyano-substituted neonicotinoids such as thiacloprid and acetamiprid appear to be metabolized more quickly by the honey bee compared to nitro-substituted ones (i.e. imidacloprid, clothianidin). The enzyme that metabolizes thiacloprid very efficiently but lacking impact against imidacloprid was recently identified as a single cytochrome P450, CYP9Q3 (Manjon et al., 2018). As we did not analyze metabolites, this could additionally have contributed to decrease the in-hive concentration of the pesticide by bees processing the syrup.

For $\tau$-fluvalinate, likewise high maximum residue values are reported. Due to their lipophilic property residues are concentrated and accumulated within the beeswax and can exceed 15 $\mathrm{mg} / \mathrm{kg}$ (Berry et al., 2013) which is in the range of $\tau$-fluvalinate residues in our experimental colonies after long-term treatment with Apistan ${ }^{\circledR}$ strips. Bogdanov et al. (1998) confirmed an increase of residues with the duration of the strip exposition with a plateau of about 40 to 60 $\mathrm{mg} / \mathrm{kg}$ after six months whereas other authors found values between 6.6 and $200 \mathrm{mg} / \mathrm{kg}$ (Mullin et al., 2010; Adamczyk et al., 2010; Tsigouri et al., 2004). 
However, even these residue levels of thiacloprid and $\tau$-fluvalinate are considered to have no acute toxicity to bees or brood (Iwasa et al., 2004; Sanchez-Bayo and Goka, 2014). In our worst case approach we examined whether a long-term exposure to field-realistic peak concentrations of the two pesticides - applied alone or in combination - impairs the development of honey bee colonies under field conditions. In two approaches performed in two consecutive years and using an identical experimental setup we could not detect any negative impact of the treatments on the population of bees and brood and on the overwintering of the colonies. Our moderate overwintering losses of about $15 \%$ (20\% in the first and $8 \%$ in the second winter) are within the range of common winter losses in free flying colonies in Germany and United States (Genersch et al., 2010; Lee et al., 2015) and affected all except the "Fluvalinate" group. Probably, the higher mite load in the untreated groups has contributed to these slightly higher overwintering losses. The mite infestation was quantified in late autumn/winter by an oxalic acid treatment which is known to be highly effective against Varroa mites, given that bees are in their winter cluster without brood (Rademacher and Harz, 2006). With the treatment we could also verify that the colonies treated with $\tau$ fluvalinate were sufficiently exposed to this compound during the season, resulting in lower dead mite drops compared to the two groups not treated with $\tau$-fluvalinate. Remarkably, in the winter treatment of the second season our colonies already showed signs of an established $\tau$ fluvalinate resistance in the Varroa mite population at our apiary. Such resistance was often reported in the past all over the world (Lodesani et al., 1995; Elzen et al., 1999; GraciaSalinas et al., 2006; Alissandrakis et al., 2017).

In both years the population of bees and brood was evaluated eight times in a total of $8-9$ colonies per treatment group. Only in very few cases significant group differences were recorded. In the first year (2010/2011), the control colonies were slightly weaker at the start of the experiment in spring/summer but revealed no differences any more in the autumn and after-winter evaluations. Although all experimental colonies were established from artificial swarms of approximately the same weight it is not unusual that there are small differences in the first weeks of development in newly established honey bee colonies (Imdorf et al., 2008).

297 In the second year (2011/2012) the "Thiacloprid" group had a significant lower number of 298 brood cells in August, however without differences in the two consecutive assessments and without significant effects on the adult bee population. More importantly, there were no group 300 differences at all in the assessments before and after overwintering, indicating no effects of 301 the pesticide treatment on this crucial colony performance. In a previous study performed in observation hives we could already confirm that behavioral traits like flight activity, 
antennation, grooming and trophallaxis are not affected by the chronic exposure to high concentrations $(1 \mathrm{mg} / \mathrm{kg})$ of thiacloprid (Retschnig et al., 2015). The authors therefore assumed a rather weak impact of the pesticide treatment.

306 Our results are also in agreement with a three-year study of Siede et al. (2017) who 307 chronically applied two different thiacloprid concentrations $(0.2 \mathrm{mg} / \mathrm{kg}$ and $2 \mathrm{mg} / \mathrm{kg})$ and could also not confirm any negative impairment on colony health and winter survival. Interestingly, they also found a significant lower amount of brood cells in colonies fed with the high thiacloprid concentration but equally to our results no effect on the colony strength or overwintering was noticed. In contrast to other neonicotinoids (Blacquiere et al., 2012) there has been no prove of acute toxicity of thiacloprid to brood; however, according to our results and those of Siede at al. (2017) this aspect should be considered in future approaches. Berry et al., (2013) could also show for $\tau$-fluvalinate, that exposure to high concentrations in beeswax did not have measurable effects on the amount of brood, amount of honey, foraging rate, time required for marked bees released to return to their hive, percentage of released bees that return to the hive, and colony Nosema spore loads. In addition, we here could prove for the first time that a combination of this acaricide with the neonicotinoid insecticide did not have measurable synergistic effects at the colony level.

320 However, our study is in contrast to many laboratory and semi-field studies providing 321 evidence for negative effects of thiacloprid such as elevated mortality under stress (Doublet et al., 2015) or in combination with pathogens (Vidau et al., 2011), impaired navigation (Fischer et al., 2014), reduced immunocompetence (Brandt et al., 2016), disrupted learning and memory functions (Tison et al., 2017) as well as affected social behavior (Forfert and Moritz 2017; Tison et al., 2016). In most of these studies individual bees were exposed to different concentrations of thiacloprid over a certain time period and subsequently challenged to various physiological tests. The findings were then extrapolated to the colony level without confirmation under field conditions. For example, Tison et al. (2016) found foraging behavior and social communication impaired when applying a concentration of $4.5 \mathrm{mg} / \mathrm{kg}$ thiacloprid 330 over one week in a free flying feeder experiment. This exposure corresponds to a 23 -fold 331 higher concentration than the maximum value for thiacloprid residues accepted for honey in the EU (0.2 mg/kg; EFSA, 2016). It seems unlikely that honey bees are chronically exposed

333 to such high concentrations under realistic field conditions. Additionally, it makes a 334 difference whether pesticides are applied to individual bees under artificial conditions or to 335 bees within a free flying colony. Obviously, the damage threshold of the honey bee colony as 
336 a huge social entity is different from the threshold calculated from the effects on individual 337 bees. This "buffering effect" of the colony has frequently been discussed, however without a 338 final explanation of the underlying mechanisms (Straub et al., 2015; Sponsler and Johnson, 339 2017). Recently, Odemer at al. (2018) could demonstrate that even the highly bee toxic 340 neonicotinoid clothianidin is significantly less toxic when applied to bees that are kept within 341 the social environment of a colony.

342 Our results might contribute to the current discussion about the ban of neonicotinoids in 343 agricultural practice which recently led to an assessment of the EFSA considering three 344 neonicotinoids (clothianidin, thiametoxam and imidacloprid) a "risk to bees" (EFSA, 2018). It 345 is an important issue for the agricultural production and for environmental protection, whether 346 neonicotinoids with substantially lower bee toxicity should also be banned. Our results 347 indicate that at least for honey bees the risk is low. It is likely that wild bees or other 348 pollinating insects are more susceptible to thiacloprid as it has been shown already for bumble 349 bees (Ellis et al., 2017), however more field data on the population level of wild pollinators 350 are necessary for a reliable risk assessment of thiacloprid.

356 Disclosure statement

No potential conflict of interest was reported by the authors. 


\section{REFERENCES}

Adamczyk S, Lázaro R, Pérez-Arquillué C, Bayarri S, Herrera A (2010) Impact of the use of fluvalinate on different types of beeswax from Spanish hives. Arch Environ Contam Toxicol 58:733-739. doi: 10.1007/s00244-009-9387-7

Alaux C, Brunet FR JL, Dussaubat C, Mondet F, Tchamitchan S, Cousin M, Brillard J, Baldy A, Belzunces LP, Le Conte Y (2010) Interactions between Nosema microspores and a neonicotinoid weaken honeybees (Apis mellifera). Environ Microbiol 12:774-782. doi: $10.1111 / \mathrm{j} .1462-2920.2009 .02123 . x$

Alissandrakis E, Ilias A, Tsagkarakou A (2017) Pyrethroid target site resistance in Greek populations of the honey bee parasite Varroa destructor (Acari: Varroidae). J Apic Res 56:625-630. doi: 10.1080/00218839.2017.1368822

Berry JA, Hood WM, Pietravalle S, Delaplane KS (2013) Field-Level Sublethal Effects of Approved Bee Hive Chemicals on Honey Bees (Apis mellifera L). PLoS One. doi: 10.1371/journal.pone.0076536

Blacquière T, Smagghe G, Van Gestel CAM, Mommaerts V (2012) Neonicotinoids in bees: A review on concentrations, side-effects and risk assessment. Ecotoxicology 21:973-992. doi: 10.1007/s10646-012-0863-x

Bogdanov S, Kilchenmann V, Imdorf A (1998) Acaricide residues in some bee products. J Apic Res 37:57-67. doi: 10.1080/00218839.1998.11100956

Brandt A, Gorenflo A, Siede R, Meixner M, Büchler R, B??chler R (2016) The neonicotinoids thiacloprid, imidacloprid, and clothianidin affect the immunocompetence of honey bees (Apis mellifera L.). J Insect Physiol 86:40-47. doi: 10.1016/j.jinsphys.2016.01.001

Brunet J-L, Badiou A, Belzunces LP (2005) In vivo metabolic fate of [14C]-acetamiprid in six biological compartments of the honeybee,Apis mellifera L. Pest Manag Sci 61:742748. doi: $10.1002 /$ ps.1046

Carreck NL (2017) A beekeeper's perspective on the neonicotinoid ban. Pest Manag Sci 73:1295-1298. doi: 10.1002/ps.4489

Cornman RS, Tarpy DR, Chen Y, Jeffreys L, Lopez D, Pettis JS, VanEngelsdorp D, Evans JD (2012) Pathogen Webs in Collapsing Honey Bee Colonies. PLoS One 7:e43562. doi: 10.1371/journal.pone.0043562

Doublet V, Labarussias M, de Miranda JR, Moritz RFA, Paxton RJ (2015) Bees under stress: Sublethal doses of a neonicotinoid pesticide and pathogens interact to elevate honey bee mortality across the life cycle. Environ Microbiol 17:969-983. doi: 10.1111/14622920.12426 
EFSA (2013) COMMISSION IMPLEMENTING REGULATION (EU) No 485/2013 of 24 May 2013 amending Implementing Regulation (EU) No 540/2011, as regards the conditions of approval of the active substances clothianidin, thiamethoxam and imidacloprid, and prohibiting the use and s. Off J Eur Union L 139:12-26.

EFSA (2016) Modification of the existing maximum residue level for thiacloprid in honey. EFSA J 14:1-21. doi: 10.2903/j.efsa.2016.4418

EFSA (2018) Evaluation of the data on clothianidin, imidacloprid and thiamethoxam for the updated risk assessment to bees for seed treatments and granules in the EU. EFSA Support Publ 15:1-31. doi: 10.2903/sp.efsa.2018.EN-1378

Ellis C, Park KJ, Whitehorn P, David A, Goulson D (2017) The Neonicotinoid Insecticide Thiacloprid Impacts upon Bumblebee Colony Development under Field Conditions. Environ Sci Technol 51:1727-1732. doi: 10.1021/acs.est.6b04791

Elzen P, Eischen F, Baxter J, Elzen G, Wilson W (1999) Detection of resistance in US Varroa jacobsoni Oud.(Mesostigmata: Varroidae) to the acaricide fluvalinate. Apidologie 30:1317. doi: doi.org/10.1051/apido:19990102

Fischer J, Müller T, Spatz A-K, Greggers U, Grünewald B, Menzel R (2014) Neonicotinoids interfere with specific components of navigation in honeybees. PLoS One 9:e91364. doi: 10.1371/journal.pone.0091364

Forfert N, Moritz RFA (2017) Thiacloprid alters social interactions among honey bee workers (Apis mellifera). J Apic Res 56:467-474. doi: 10.1080/00218839.2017.1332542

Garrido PM, Porrini MP, Antúnez K, Branchiccela B, Martínez-Noël GMA, Zunino P, Salerno G, Eguaras MJ, Ieno E (2016) Sublethal effects of acaricides and Nosema ceranae infection on immune related gene expression in honeybees. Vet Res 47:51. doi: $10.1186 / \mathrm{s} 13567-016-0335-\mathrm{Z}$

Genersch E, Von Der Ohe W, Kaatz H, Schroeder a, Otten C, Büchler R, Berg S, Ritter W, Mühlen W, Gisder S, Meixner M, Liebig G, Rosenkranz P (2010) The German bee monitoring project: A long term study to understand periodically high winter losses of honey bee colonies. Apidologie 41:332-352. doi: 10.1051/apido/2010014

Gracia-Salinas MJ, Ferrer-Dufol M, Latorre-Castro E, Monero-Manera C, Castillo-Hernández J, Lucientes-Curd J, Peribáñez-López MA (2006) Detection of fluvalinate resistance in Varroa destructor in Spanish apiaries. J Apic Res 45:101-105. doi: 10.1080/00218839.2006.11101326

Henry M, Beguin M, Requier F, Rollin O, Odoux J-F, Aupinel P, Aptel J, Tchamitchian S, Decourtye A (2012) A Common Pesticide Decreases Foraging Success and Survival in Honey Bees. Science (80- ) 336:348-350. doi: 10.1126/science.1215039

Imdorf A, Buehlmann G, Gerig L, Kilchenmann V (1987) Überprüfung der Schätzmethode zur Ermittlung der Brutfläche und der Anzahl Arbeiterinnen in freifliegenden Bienenvölkern. Apidologie 18:137-146. doi: http://dx.doi.org/10.1051/apido:19870204 
Imdorf A, Ruoff K, Fluri P (2008) Volksentwicklung bei der Honigbiene. ALP forum, (68), 2008, 1-88. ISSN Print: 1661-0814

Iwasa T, Motoyama N, Ambrose JT, Roe RM (2004) Mechanism for the differential toxicity of neonicotinoid insecticides in the honey bee, Apis mellifera. Crop Prot 23:371-378. doi: $10.1016 /$ j.cropro.2003.08.018

Jeschke P, Nauen R, Schindler M, Elbert A (2011) Overview of the status and global strategy for neonicotinoids. J Agric Food Chem 59:2897-908. doi: 10.1021/jf101303g

Laaniste A, Leito I, Rebane R, Lõhmus R, Lõhmus A, Punga F, Kruve A (2016) Determination of neonicotinoids in Estonian honey by liquid chromatographyelectrospray mass spectrometry. J Environ Sci Heal Part B 51:455-464. doi: 10.1080/03601234.2016.1159457

Lee K V., Steinhauer N, Rennich K, Wilson ME, Tarpy DR, Caron DM, Rose R, Delaplane KS, Baylis K, Lengerich EJ, Pettis J, Skinner JA, Wilkes JT, Sagili R, VanEngelsdorp D (2015) A national survey of managed honey bee 2013-2014 annual colony losses in the USA. Apidologie 46:292-305. doi: 10.1007/s13592-015-0356-Z

Lodesani M, Colombo M, Spreafico M (1995) Ineffectiveness of Apistan ${ }^{\circledR}$ treatment against the mite Varroa jacobsoni Oud in several districts of Lombardy (Italy). Apidologie 26:67-72. doi: doi.org/10.1051/apido:19950109

Manjon C, Troczka BJ, Zaworra M, Beadle K, Randall E, Hertlein G, Singh KS, Zimmer CT, Homem RA, Lueke B, Reid R, Kor L, Kohler M, Benting J, Williamson MS, Davies TGE, Field LM, Bass C, Nauen R (2018) Unravelling the Molecular Determinants of Bee Sensitivity to Neonicotinoid Insecticides. Curr Biol 1-7. doi: 10.1016/j.cub.2018.02.045

Matsumoto T (2013) Reduction in homing flights in the honey bee Apis mellifera after a sublethal dose of neonicotinoid insecticides. Bull Insectology 66:1-9.

Mitchell EAD, Mulhauser B, Mulot M, Mutabazi A, Glauser G, Aebi A (2017) A worldwide survey of neonicotinoids in honey. Science (80- ) 358:109-111. doi: $10.1126 /$ science.aan3684

Mullin C a, Frazier M, Frazier JL, Ashcraft S, Simonds R, Vanengelsdorp D, Pettis JS (2010) High levels of miticides and agrochemicals in North American apiaries: implications for honey bee health. PLoS One 5:e9754. doi: 10.1371/journal.pone.0009754

Odemer R, Nilles L, Linder N, Rosenkranz P (2018) Sublethal effects of clothianidin and Nosema spp. on the longevity and foraging activity of free flying honey bees. Ecotoxicology. doi: 10.1007/s10646-018-1925-5 
Pohorecka K, Skubida P, Miszczak A, Semkiw P, Sikorski P, Zagibajło K, Teper D, Kołtowski Z, Skubida M, Zdańska D, Bober A (2012) Residues of Neonicotinoid Insecticides in Bee Collected Plant Materials from Oilseed Rape Crops and their Effect on Bee Colonies. J Apic Sci 56:115-134. doi: 10.2478/v10289-012-0029-3

Rademacher E, Harz M (2006) Oxalic acid for the control of varroosis in honey bee colonies - a review. Apidologie 37:98-120. doi: 10.1051/apido:2005063

Retschnig G, Williams GR, Odemer R, Boltin J, Di Poto C, Mehmann MM, Retschnig P, Winiger P, Rosenkranz P, Neumann P (2015) Effects, but no interactions, of ubiquitous pesticide and parasite stressors on honey bee ( A pis mellifera ) lifespan and behaviour in a colony environment. Environ Microbiol 17:4322-4331. doi: 10.1111/1462-2920.12825

Rosenkranz P, Aumeier P, Ziegelmann B (2010) Biology and control of Varroa destructor. J Invertebr Pathol 103 Suppl:S96-119. doi: 10.1016/j.jip.2009.07.016

Rosenkranz P, von der Ohe W, Schäfer M, Genersch E, Büchler R, Berg S, Otten C (2016) Veröffentlichungen und Berichte Website Deutsches Bienenmonitoring - „DeBiMo“. https://goo.gl/JBj8LC, Accessed 18 March 2018

Sanchez-Bayo F, Goka K (2014) Pesticide Residues and Bees - A Risk Assessment. PLoS One 9:e94482. doi: 10.1371/journal.pone.0094482

Schmuck R, Stadler T, Schmidt H-W (2003) Field relevance of a synergistic effect observed in the laboratory between an EBI fungicide and a chloronicotinyl insecticide in the honeybee (Apis mellifera L, Hymenoptera). Pest Manag Sci 59:279-86. doi: $10.1002 /$ ps. 626

Siede R, Faust L, Meixner MD, Maus C, Grünewald B, Büchler R (2017) Performance of honey bee colonies under a long-lasting dietary exposure to sublethal concentrations of the neonicotinoid insecticide thiacloprid. Pest Manag Sci 73:1334-1344. doi: $10.1002 /$ ps. 4547

Smodis Skerl MI, Velikonja Bolta S, Basa Cesnik H, Gregorc A (2009) Residues of Pesticides in honeybee (Apis mellifera carnica) bee bread and in pollen loads from treated apple orchards. Bull Environ Contam Toxicol 83:374-7. doi: 10.1007/s00128009-9762-0

Straub L, Williams GR, Pettis J, Fries I, Neumann P (2015) Superorganism resilience: eusociality and susceptibility of ecosystem service providing insects to stressors. Curr Opin Insect Sci 12:109-112. doi: 10.1016/j.cois.2015.10.010

Sponsler DB, Johnson RM (2017) Mechanistic modeling of pesticide exposure: The missing keystone of honey bee toxicology. Environ Toxicol Chem 36:871-881. doi: 10.1002/etc.3661

Tison L, Hahn M-L, Holtz S, Rößner A, Greggers U, Bischoff G, Menzel R (2016) Honey Bees' Behavior Is Impaired by Chronic Exposure to the Neonicotinoid Thiacloprid in the Field. Environ Sci Technol 50:7218-7227. doi: 10.1021/acs.est.6b02658 
Tison L, Holtz S, Adeoye A, Kalkan Ö, Irmisch NS, Lehmann N, Menzel R (2017) Effects of sublethal doses of thiacloprid and its formulation Calypso ${ }^{\circledR}$ on the learning and memory performance of honey bees. J Exp Biol 220:3695-3705. doi: 10.1242/jeb.154518

Tsigouri AD, Menkissoglu-Spiroudi U, Thrasyvoulou A, Diamantidis G (2004) Fluvalinate Residues in Honey and Beeswax after Different Colony Treatments. Bull Environ Contam Toxicol 72:975-982. doi: 10.1007/s00128-004-0339-7

Vidau C, Diogon M, Aufauvre J, Fontbonne R, Viguès B, Brunet JL, Texier C, Biron DG, Blot N, Alaoui H, Belzunces LP, Delbac F (2011) Exposure to sublethal doses of fipronil and thiacloprid highly increases mortality of honeybees previously infected by nosema ceranae. PLoS One 6:e21550. doi: 10.1371/journal.pone.0021550

Wallner K (1999) Varroacides and their residues in bee products. Apidologie 30:235-248. doi: doi.org/10.1051/apido:19990212

Wang R, Liu Z, Dong K, Elzen PJ, Pettis J, Huang Z (2002) Association of novel mutations in a sodium channel gene with fluvalinate resistance in the mite, Varroa destructor. J Apic Res 41:17-25. doi: 10.1080/00218839.2002.11101064

Watkins M (1997) Resistance and its relevance to beekeeping. Bee World 78:15-22. doi: 10.1080/0005772X.1997.11099327

Wu JY, Smart MD, Anelli CM, Sheppard WS (2012) Honey bees (Apis mellifera) reared in brood combs containing high levels of pesticide residues exhibit increased susceptibility to Nosema (Microsporidia) infection. J Invertebr Pathol 109:326-9. doi: 10.1016/j.jip.2012.01.005

Würfel T (2008) Abschlussbericht Beizung und Bienenschäden. Minist für Ernährung und ländlichen Raum 1-40. https://goo.gl/LMuN5g, Accessed 10 December 2017 